University of Nebraska - Lincoln

DigitalCommons@University of Nebraska - Lincoln

To Improve the Academy

Professional and Organizational Development Network in Higher Education

1997

\title{
Small Group Techniques: Selecting and Developing Activities Based on Stages of Group Development
}

Sandra A. Harris

Kathryn J. Watson

Follow this and additional works at: https://digitalcommons.unl.edu/podimproveacad

Part of the Higher Education Administration Commons

Harris, Sandra A. and Watson, Kathryn J., "Small Group Techniques: Selecting and Developing Activities Based on Stages of Group Development" (1997). To Improve the Academy. 378.

https://digitalcommons.unl.edu/podimproveacad/378

This Article is brought to you for free and open access by the Professional and Organizational Development Network in Higher Education at DigitalCommons@University of Nebraska - Lincoln. It has been accepted for inclusion in To Improve the Academy by an authorized administrator of DigitalCommons@University of Nebraska - Lincoln. 
Harris, S. A., \& Watson, K.J. (1997). Small group lochniques: Selecting and developing activities besed on stages of group development. In D. DeZure (Ed), To Improve the Academy, Vol. 16 (pp. 399-412). Stillwater, OK: New Forums Press and the Professional and Organizational Development Network in Higher Ecucation. Key Words: Active Leaming, Cooperative Learning.

\section{Small Group Techniques: Selecting and Developing Activities Based on Stages of Group Development}

\section{Sandra A. Harris}

\section{Kathryn J. Watson}

Eckerd College

Research shows that active and cooperative learning activities can be effective teaching methods; however, developing and carrying out these practices is often challenging, perhaps even confusing and frustrating, to educators who have not been trained in group processes. This article reviews basic principles for using group techniques in college classrooms, describes the developmental stages of groups, and provides examples of activities and assignments as well as processes for reflection and evaluation.

Uncertainty about the potential benefits and costs of using group activities in college classes is common. In this article, we identify goals and objectives for group activities, describe appropriate exercises for different purposes, and examine the necessity for reflection and processing that lead to meaningful learning from group experiences. We delineate the stages that often characterize group development and 
suggest tasks appropriate for each stage. Our ideas are applicable in small and large classes in all disciplines for those who want to design effective small group learning activities and assignments; enhance existing group activities and interactive strategies; understand why certain group strategies have worked and others have not; and build community within the classroom so that open, in-depth learning exchanges occur among students.

\section{Background and Rationale}

In the 1960's William Perry applied the pioneering work of Piaget to the college setting, documenting in his classic study of intellectual development that learning - even at the college level-was enhanced by doing (Perry, 1968). More recently, educators have begun to study collaborative and cooperative learning, noting its positive impact on students (Bruffee, 1993; Cohen, 1986; Goodsell, Maher, \& Tinto, 1992; Johnson \& Johnson, 1989). Increasingly, faculty across the disciplines have begun to discover the benefits of incorporating small group activities in the classroom (Kadel \& Keehner, 1994; Michaelson, Fink, \& Black, 1996). Perhaps even more important, college alumni have begun to inform us that the most crucial skill (and the one most often neglected in their undergraduate programs) is how to function as a member of a problem-solving group (Light, 1990, 1991).

Proponents of active learning suggest that using small group techniques in the classroom consistently enhances learning (Angelo \& Cross, 1993; Bonwell \& Eison, 1991). Students who collaborate with each other in defining, exploring, and solving problems as members of cooperative groups develop social and communication skills and refine their skills of analysis and judgment. Through their active engagement in concretely applying content material, they become more interested and involved in learning and more confident about their own strengths and abilities (Astin, 1987; Richlin \& Cox, 1994). The positive outcomes of such active learning can extend beyond the classroom; in fact, "... involvement in learning, involvement with other students, and involvement with faculty are factors that make an overwhelming difference in student retention and success in college" (Goodsell, Maher, \& Tinto, 1992, p. 11). 


\section{Review of Basic Principles of Grouping}

When college faculty begin to set up group activities, they quickly realize that designing effective group work is challenging. Successful implementation requires meticulous preparation; it does not just happen spontaneously. Group work, to be valued and valuable, cannot be "busy work" Students need to have a sense of accomplishment as a result of their participation in group work. Professors who include group work in their courses must make changes that alter the structure, form and content of their classes. The roles and responsibilities of teachers and students change. Learning, usually viewed as private and idiosyncratic, becomes public, open to question and discussion. No longer is it only the teacher who is on stage. When everyone participates, students share (and sometimes even control) the limelight.

Small group work can enhance learning in many ways (Cottell \& Millis, 1994), but it is important to establish why small group work is desirable for each particular course. Group activities should grow out of a learning-based rationale. Primary goals for small group activities are to create a trusting, cooperative atmosphere for later class discussions; develop effective groups for class projects; develop effective, complex, cooperative learning or problem-solving groups; prepare for out-of-class study groups; reach people with different learning styles; and illustrate course content.

Group activities should not merely be viewed as "fun" or as filler to break up the monotony of a syllabus or as something for the class to do when the professor has to be out of town. Those who want to incorporate group strategies in their teaching should think comprehensively about the components of each course: content, goals and objectives, relationship to general education courses and placement in the sequence of courses in the discipline. What elements should be emphasized? What skills should be taught? What is the appropriate balance between lectures and group work? What types of examinations should be administered? How can group work be made relevant to this course? To be effective, group work must require learning, not merely completing tasks. Proponents of group activities note that uneven performance and "slacking off" are most likely to occur when a group is given only a single task (one worksheet, one report, one 
project) rather than an assignment that requires that each individual in the group fulfill a unique and integral role (Cottell \& Millis, 1994; Goodsell, et al., 1992).

The composition of a group also has a decisive impact on the success or failure of the group. The objectives for a particular class session and its timing in the semester should determine the focus, size and composition of each group. Early in a course, when students are just becoming acquainted with each other, random and varied group assignments are appropriate. Students are more likely to have positive experiences in groups when the professor forms the groups. Successful groups require a critical mass of serious, task-oriented students. For example, an introductory group activity on the first day of class might involve everyone in randomly formed dyads or triads as they learn each other's names; for a later problem-solving activity in the same class, the professor might divide students into heterogeneous groups with only 3-5 members. Creating diversity by thoughtfully assigning individuals to each group is often advantageous (mixing a sophomore, junior, and a senior in each group; mixing majors within a group; or maintaining gender, age, or ethnic ratios across groups). Students develop greater cohesiveness and value the group experience more if they are assigned to "permanent" groups during the semester, rather than changing groups with each activity (Goodsell, et al., 1992).

Timing is crucial. Professors must carefully sequence activities throughout the semester so that students move from the getting acquainted stage through the transitional stages of working together. At every stage, clarity of purpose and explicit instructions are prerequisites for successful group work. Professors intuitively know what extensive research has shown about group development: Groups, like individuals, evolve over time and develop distinct personalities (Corey \& Corey, 1987; Forsyth, 1990).

Successful group work demands the professor's attention. Assigning students to groups to complete a task while the professor leaves the room is not good practice. It does not elicit top performance from groups. Well-planned group work requires that professors are involved in the process from beginning to end. Faculty must know their students, individually and collectively, to set up groups wisely. They must give clear, explicit instructions and be available for questions 
and support while the groups begin their work. Faculty should be a visible presence in the room, unobtrusively moving from group to group as students work together. And, faculty must close the class session, leaving time for reflection and assessment when they conclude the activities.

Setting aside a time for reflection, evaluation, and discussion of the process is a critical part of the group experience. Neglecting this processing phase can add to the students' misperception that group activities are merely "fun things" that take up class time. This misperception can lead students to dismiss the learning that has taken place, viewing it as serendipitous. Even students with sophisticated linguistic or analytical skills are often unaware of the sequence of actions and outcomes within an active group. They typically respond that "things just happened" and they need the professor to guide them through an objective observation of individual behaviors (both active and passive) and their collective outcomes. Optimal learning can occur during the processing and reflection time because students identify key concepts for themselves, make connections, and organize material so that it is personally meaningful - and, therefore, memorable (Angelo \& Cross, 1993).

Reflection should be immediate and can include multiple methods. The professor can facilitate this process by building in adequate time for detailed, open discussion, thereby teaching students the reflective process through modeling; additional reflection can be encouraged through written assignments, such as reaction papers or journals (Cronin, 1992; Edwards, 1993; Thomas, 1992). Many excellent models of student- and peer-assessment are available in the sources cited at the end of this article. As students become more knowledgeable, they can assume responsibility for process observations. One method for doing this is to assign an "observer" to take notes and share a summary of their observations with the group. Another is to videotape group activities and involve the members in a critique of the process. Always, the goal is to build a comfortable and supportive, yet intellectually-challenging, effective group. 


\section{Developmental Stages of Groups}

The ability of a class to function effectively in groups evolves and develops over the semester. The class as a group, and carefully structured small groups within the class, evolve and develop over the semester (Corey \& Corey, 1987; Forsyth, 1990). Collectively, each class has a personality that reflects the combined personalities and attitudes of the individual members of the class, creating a distinctive group character. As students become more comfortable with each other, they can bring out the best in others, learn by helping, and discover new ways to approach and complete a task Conversely, the possibility of student dissatisfaction exists, often leading to less than optimal results. Matching group activities to the group's developmental stage helps to enhance group experiences, creating an environment ' that leads to more successful outcomes for everyone.

\section{Stages}

Group development goes through four stages: initial, transition, working, and ending (Corey \& Corey, 1987). The initial stage, when individuals come together to form the group, is a time of orientation and getting to know each other. Students encounter anxiety as they wonder where they will fit in the group, what the professor expects, whether they will like the group, and how others will view them. The transition stage has also been called the time of "storming and norming" (Forsyth, 1990) as students actively experience the conflict of working out their places in the group and their differences with others. Success in resolving these issues determines the level at which the group can perform tasks in the third stage-the working stage. The ending stage is the time of termination and closure. It is particularly important for consolidating and generalizing learning in the classroom, and also for giving students a feeling of accomplishment at the end of the semester. Table 1 (below) summarizes the stages a fully functioning group goes through once it is formed and includes a brief description of the characteristics of each stage. In the next section, we describe activities and assignments appropriate for each of the four postulated stages of group development. 


\begin{tabular}{|c|l|l|l|}
\hline \multicolumn{3}{|c|}{ TABLE 1 } \\
Stages of Groups
\end{tabular}




\section{Activities for Stages}

In the fields of psychology and education, many group activities have been passed along from one "generation" to the next so that we each have a particular collection based on our experiences and often without knowledge of an original source. Some authors have focused on detailing specific activities; many of these can be found in the references cited at the end of this article. Educators interested in group activities are always alert to new ideas and modifications of existing or so-called individual activities that can be effective for groups.

\section{Initial Stage Activities}

Because the initial stage is a time for group members to get to know each other and to get past the initial anxiety that accompanies working with people for the first time, "icebreakers" or "warm-ups" are useful. These activities can range from sedate (dyadic introductions) to boisterous (the ball game). The following generic examples illustrate activities appropriate for this stage.

Dyadic Introductions. Dyads spend five minutes getting to know each other; then each person introduces the other person to the class.

Circle Introductions. Students form a small inner circle with their backs to each other and an outer circle facing the inner circle. Using sentence stems prepared by the professor (e.g., "I am taking this class because..."; "I learn best when..."; "When I am frustrated, I..."), students in the outer circle ask the first question and talk about it briefly with their "partners." The professor calls time and students in the outer circle then move to the left and ask the next question of the next person in the inner circle. This continues until the outer circle has returned to the starting person.

Ball Game. This exercise is particularly good for first-year students in classes where students do not know each other. The class stands and forms a large circle. Going around the circle, students introduce themselves by name. The professor then gives one student a small foam ball and instructs students to call someone by name and toss the ball to that student. The person receiving the ball must say, "Thank you, Megan," to the first student then repeat the process. The ball tossing continues until students begin to show some familiarity 
with a few names (they will often toss the ball to the same person each time); then the professor gives a second ball to the group and continues the game. Usually a minute with a third ball creates enough chaos and fun to end the game.

Group Definition. Another variation on this theme is the Group Definition. This may be more appropriate for a large class or used as a second-level initial activity in a small class. Informally create groups of no more than five students. Ask them to pull their desks together, introduce themselves, choose a recorder, then ask about a primary but broad concept from the course (e.g., What is an accurate definition for community mental health? What does multicultural communication mean? What is Western Heritage in a global context?). Afterward, recorders write their group's definition on the board or on a page from a flip chart that they then display. The professor facilitates a discussion of what they wrote and an analysis of similarities and differences across groups, and, depending on the course, the concepts: diversity, world perspectives, the search for truth, etc. This exercise builds relationships among students and provides a model of how a group can work together effectively. For example, the instructor might ask each small group to define a different generic concept to share with the class and ask the other groups whether they would change or add anything to the original definitions. In facilitating the discussion, the instructor will still have the opportunity to enhance or make corrections while reinforcing the students' cooperative efforts and knowledge base. In addition, this exercise would provide a baseline measure of what the students actually know compared with what the instructor might assume they know. The time invested in this type of activity will pay off later in more effective group work.

\section{Transition Stage Activities}

The transition stage of group work establishes the foundation for how well the members can work together later. This is the time when students deal with authority, leadership, and communication issues. They must figure out how to handle the challenges of personal and educational diversity and differing viewpoints about interpreting and completing an assignment. This stage is crucial for groups that will work throughout a semester or on a continuing project; it makes the 
difference between groups that have constant inner battles and perform at lower levels, and groups that are dynamic and creative, achieving more than the members could individually. The professor acts as role model, guide, facilitator, advisor, coach, and cheerleader during this time. Activities in this stage illustrate the value of group participation, highlight diverse student strengths, and build trust among members with differing viewpoints. Exercises that build trust include:

Sentence Completion Circle Games. The instructor uses sentence stems that require students to complete the same sentence from a personal perspective. For example, stems for a Western Heritage class might include: "Among all of the writers and thinkers we have studied this fall, I believe ___ has had the most significant influence on Western thought because..."; or "I believe the most profound effect of the Reformation was...because..."; or "This course has changed the way I think about..."

Diversity Exploration Exercises. For example, in "Alligator River," students must rank five characters from "best" to "worst" and state the reasons for their decisions (Cohen, 1986).

Physical Activities. Trust walks, trust falls, or ropes exercises allow students to see themselves as increasingly capable and competent because of their emerging confidence in themselves and their classmates (Rohnke, 1984).

Cognitive Games. Transition stage activities that focus on understanding how groups work and how diverse participation becomes beneficial can encompass simple problem-solving or task-oriented exercises, such as Cognitive Games. For example, Wordles (Rohnke, 1984) provide a challenging and often amusing series of word puzzles that stimulate lively group discussion. To create Straw Structures, students work in small groups to attempt to build the highest standing structure-using only materials provided by the instructor-within a ten minute period.

Problem-solving exercises such "Stranded in the Desert" and "Fallout Shelter" (Johnson \& Johnson, 1989) demand more complex solutions and can illustrate how important each person's ideas are to the group outcome. In addition, transition activities can be designed or adapted to be directly connected to specific course content. For 
example, using and discussing learning style or personality inventories (e.g., the Myers Briggs Type Indicator or the Kolb Inventory) work well in a wide range of disciplines. Creating a study guide is applicable in any class.

Cooperative Controversy Debates (Goodsell, et al., 1992) can be used for specific major issues in a course. In any particular course, professors can challenge themselves to create simple problem-solving or task-oriented exercises to promote an understanding of group interactions.

\section{Working-Stage Activities}

During the working stage, group communication and problemsolving abilities are at their peak. The effective cooperative group can work productively and autonomously on complex tasks. Members can handle conflicts that may occur within the group and achieve self-determined goals. A successful group that is truly in the working stage is easy to spot; it has a positive, enthusiastic attitude where members both support and challenge each other.

Generic working-stage activities include problem-solving exercises, such as Intergroup Conflict (Johnson \& Johnson, 1989) and Balls in the Pipe (Rohnke, 1984). The professor has been building toward this stage so that specific course-based projects and activities can be highly successful. At this point, small groups can produce outstanding class presentations or panels, creative projects, group literature review, and reach other complex, cooperative learning goals.

Nurturing or coaching small groups through the early stages will help them reach this stage of effective, autonomous group work. For example, an instructor might ask each group to complete an out-ofclass project involving content research, interviews, and a synthesis of theory with application. One caution, particularly when first attempting to develop effective groups, is to remember than even an optimal environment will not necessarily cause all students to do their best work. Written evaluations of group work can provide useful information to consider when developing the next group effort. Openended questions about "best" and "worst" aspects of this learning experience often highlight the learning style differences noted earlier. They can also emphasize the pressure students feel to complete all of 
the readings and work so that they do not let down their peers. This is in stark contrast to "getting by" with a professor who does all the talking for the class.

\section{Ending Stage Activities}

The ending stage is a time for closure and saying goodbyes. This is often an overlooked portion of the developmental process, but the more cohesive and cooperative a group has been, the more important this stage becomes. When thinking of the class objectives, such as consolidating and generalizing learning, the end-of-semester termination traditionally revolves around group project presentations and the final exam. Self and peer evaluations and sharing highlights about the semester-long learning process are also beneficial. In addition, termination is a time when people in a group recognize an end to their work together, handle it in personal ways, and separate from each other. Small cooperative classes and classes that have worked in small groups much of the semester particularly need to acknowledge their ending and formalize it together.

Traditional methods include "rounds" of feedback or farewell, small group legacy art, or a class pizza party. Activities can emphasize the content of any specific course, such as a multicultural picnic where people bring dishes representing their cultural heritage (for a crosscultural course); a campus tour where students point out the influence of western heritage on their everyday lives (for a western heritage course); or a review for finals through a group-created content game similar to Jeopardy. Small groups might naturally convene study groups for the final exam. The instructor can also use the termination stage for a "capstone" experience, such as attending a legislative session or videotaping a class version of a political talk show.

\section{Conclusion}

Using group activities in the college classroom not only leads to enhanced learning of course content, but also increases the confidence and competence of students as problem-solvers. Successful group activities grow out of a learning-based rationale and require careful planning and monitoring. The instructor must be sensitive to the 
diverse needs and expectations of the students and their varying developmental levels. Instructors who are aware of the stages through which groups evolve can match small group activities and assignments appropriately to these stages. Recognizing that most groups move through four stages (initial, transitional, working and termination) can help instructors to plan activities and assignments that lead to optimal learning at each stage. Setting aside time for reflection, evaluation and discussion is vital for successful use of small group techniques in the college classroom.

\section{References}

Angelo, T. A., \& Cross, K. P. (1993). Classroom assessment techniques: A handbook for college teachers (2nd. ed.). San Francisco: Jossey Bass.

Astin, A. (1987). Achieving educational excellence. San Francisco: Jossey-Bass.

Bonwell, C. C., \& Eison, J. A. (1991). Active learning: Creating excitement in the classroom. Washington, DC: ASHE/ERIC Clearinghouse on Higher Education.

Bruffee, K. A. (1993). Collaborative learning: Higher education, interdependence, and the authority of knowledge. Baltimore: Johns Hopkins University Press.

Cohen, E. G. (1986). Designing groupwork: Strategies for the heterogeneous classroom. New York: Teachers College Press.

Corey, M. S., \& Corey, G. (1992). Groups: Process and practice (4th ed.). Pacific Grove, CA: Brooks/Cole.

Cottell, Jr., P. G., \& Millis, B. J. (1994). Complex cooperative learning structures for college and university courses. In E. Wadsworth (Ed.), To Improve the Academy, Vol. 13, (pp. 285-307). Stillwater, OK: New Forums Press and the Professional and Organizational Development Network in Higher Education.

Edwards, H. C. (1993). Mistakes and other classroom techniques: An application of social learning theory. Journal on Excellence in College Teaching, 3, 49-60.

Finkel, D. L., \& Monk, G. S. (1979). The design of intellectual experience. The Journal of Experiential Education, 2, 31-38.

Forsyth, D. R. (1990). Group dynamics (2nd ed.). Belmont, CA: Brooks/Cole.

Goodsell, A., Maher, M., \& Tinto, V. (1992). Collaborative learning: A source book for higher education. University Park, PA: National Center on Postsecondary Teaching, Learning, \& Assessment.

Johnson, D. W. , \& Johnson, R. T. (1989). Cooperation and competition: Theory and research. Edina, $\mathrm{MN}$ : Interaction Book.

Kadel, S., \& Keenher, J. A. (1994). Collaborative learning: A sourcebook for higher education, 2. University Park, PA: National Center for Postsecondary Teaching, Learning \& Assessment. 
Light, R. (1990-1991). The Hanvard assessment seminars: Explorations with students and faculty about teaching, learning, and student life. Cambridge, MA: Harvard University Press.

Michaelson, L. K., Fink, L. D., \& Black, R. H. (1990). What every faculty developer needs to know about learning groups. In L. Richlin (Bd), To Improve the Academy, Vol. 15, (pp. 31-57). Stillwater, OK: New Forums Press and the Professional and Organizational Development Network in Higher Education.

Perry, W. O. (1968). Forms of intellectual and ethical development in the college years. New York: Rinehart \& Winston, Inc.

Richlin, L., \& Cox, M. D. (1994). Teaching, learning and the student-teacher relationship: A message from the editors. Journal on Excellence in College Teaching, 5, 1-3.

Rohnke, K. (1984). Silver bullets: A guide to initiative problems, actventure games and trust activities. Dubuque, IA: Kendall/Hunt.

Schmuck, R. A., \& Schmuck, P. A. (1992). Group processes in the classroom (6th ed.). Dubuque, IA: William C. Brown.

Thomas, T. (1992). Connected teaching: An exploration of the classroom enterprise. Journal on Excellence in College Teaching, 3, 101-119.

Contact:

Kathryn J. Watson

Associate Dean for Faculty Development

Eckerd College

4200 54th Avenue South

St. Petersburg, Florida 33711

(813) 864-8474

(813) 864-7890 FAX

watsonkj@eckerd.edu

Kathryn J. Watson was a 1993-1994 American Council on Education Fellow at Denison University. She is Associate Dean for Faculty Development and Intergenerational Leaming and Professor of Education at Eckerd College. She teaches courses in group dynamics, education and human development, and environmental studies, and coordinates new faculty orientation and faculty development programs. She is the curriculum consultant for the NSF/NEH grant to develop an interdisciplinary Envirommental Studies major at Eckerd College and serves as project coordinator for the CAPHE Grant on Faculty Roles and Rewards.

Sandra A. Barris is Associate Professor of Human Development. She teaches courses in socialization, gender, child roles and family systems, and counseling strategies. She has studied groups in Greece, Japan and Hawaii and is a member of the ASIANetwork. 